\title{
Lusisersily
}

\section{Glacial geomorphological map of the western margin of the British Irish Ice Sheet on the Irish continental shelf}

Dunlop, P., Benetti, S., \& Ó Cofaigh, C. (2012). Glacial geomorphological map of the western margin of the British Irish Ice Sheet on the Irish continental shelf: Quaternary International 279-280 (2012) 121-232. $125-126$. Poster session presented at XVIII INQUA Congress.. https://doi.org/10.1016/j.quaint.2012.08.029

Link to publication record in Ulster University Research Portal

Publication Status:

Published (in print/issue): 01/11/2012

DOI:

https://doi.org/10.1016/j.quaint.2012.08.029

\section{Document Version}

Publisher's PDF, also known as Version of record

\section{General rights}

Copyright for the publications made accessible via Ulster University's Research Portal is retained by the author(s) and / or other copyright owners and it is a condition of accessing these publications that users recognise and abide by the legal requirements associated with these rights.

\section{Take down policy}

The Research Portal is Ulster University's institutional repository that provides access to Ulster's research outputs. Every effort has been made to ensure that content in the Research Portal does not infringe any person's rights, or applicable UK laws. If you discover content in the Research Portal that you believe breaches copyright or violates any law, please contact pure-support@ulster.ac.uk. 
stadial conditions. Furthermore, it seems the strong insolation increase at this time had little noticeable effect on ice-sheet dynamics over the northern continents, suggesting that tropical - high latitude coupling maybe either a transient feature or more complicated than previously thought.

\section{QUANTIFYING INTERGLACIAL CLIMATE VARIABILITY FROM A CA. 1 MILLION-YEAR SPELEOTHEM RECORD USING A MULTI-PROXY APPROACH}

Russell Drysdale. The University of Melbourne, Australia

E-mail address: rnd@unimelb.edu.au

Evidence from Antarctic ice cores shows that the duration of past interglacials changes from one cycle to the next. These ice cores also show that the degree of climate variability within interglacials (i.e. the intra-interglacial variability) also changes from one to the next, and very few, if any, interglacials are 'the same' in this regard. We can crudely verify the variability in duration of interglacials as observed in the ice record using marine core records, but it is difficult to do the same for intra-interglacial variability because there are few coeval marine (and terrestrial) records with adequate sampling resolution by which to achieve this. In this paper, we explore intra-interglacial variability using speleothems from Corchia Cave (Italy). Our speleothem archive includes a near-continuous sequence from a single subaqueous deposit extending back over the last 960,000 years, which reduces possible inter-speleothem variability that may arise from relying solely on stalagmites and flowstones. We complement stable oxygen and carbon isotope and trace element data with information on organic content derived from spectrofluorescence measurements to examine the degree of intra-interglacial variability over the last million years. We compare this speleothem record to ice, marine and astronomical data and explore whether orbital forcing plays a role in controlling intrainterglacial climate.

WHAT IS LEFT OF THE BADEGOULIAN "INTERLUDE"? TECHNOECONOMIC REASSESSMENT OF A HISTORIOGRAPHIC “NORM”

Sylvain Ducasse. University of Toulouse 2 / TRACES - UMR 5608, France E-mail address: sylvain.ducasse@univ-tlse2.fr

In France, the second part of the Upper Paleolithic witnesses an abrupt change in the evolution of technological traditions: around 19,500 BP $(23,000$ Cal BP), the Solutrean industries disappear and are replaced by very different Badegoulian industries. First considered as the beginning of the Magdalenian, the Badegoulian was then re-evaluated as an independent archaeological culture, and at the end of the 90s, it was considered as an atypical and discordant industry, without clear links with the preceding and the following ones. This work aims to question this position and to reexamine the reality of the "Badegoulian interlude" through the analysis of different lithic industries from Southern France. Then we'll try to describe and understand its reasons and mechanism. Through a dynamic reconstruction of the lithic technical system we are able to confirm the sharp and deep break that separates the Solutrean and Badegoulian technoeconomic worlds. Without denying the differences between the Badegoulian and the Magdalenian (in particular in bone working techniques), we are also able to argue that the Badegoulian truly gives root to the Magdalenian culture around 17,500 BP (20,500 Cal BP).

\section{CENTRAL EUROPEAN VEGETATION OF THE EARLY AND MIDDLE HOLOCENE AS SEEN FROM THE SOUTHERN URALS}

Lydie Dudová. Masaryk University, Czech Republic

E-mail address: cvilinek@gmail.com

Modern vegetation and environments of the Southern Urals are very similar to those of Early and Middle Holocene Central Europe. This area lies outside the distribution range of beech and hornbeam, whose invasion to Central Europe in the Late Holocene significantly changed species composition of forest vegetation. At the same time, it contains tree species that were found in Early to Middle Holocene Central Europe, such as oak, elm, lime, maple, birch, pine and larch, combined with steppe vegetation. Therefore the modern pollen data from the Southern Urals can provide key insights into understanding of processes and patterns within the landscape of mixed oak forests of the Middle Holocene Central Europe. Since pollen record is the main source of information on past vegetation, we have analyzed 50 surface pollen samples obtained in six main vegetation types of the Southern Urals: dry steppe, mesic steppe, hemiboreal coniferous pine-larch forest, small-leaved birch-aspen forest, broad-leaved oak forest and broad-leaved maple-lime-elm forest. In turn, these types represent the main vegetation units as they had replaced one another from the Late Glacial/Holocene transition to the Middle Holocene. The relationships between modern pollen spectra, modern vegetation and abiotic site conditions were studied. Space-for-time substitution provided a framework for fossil-pollen-based reconstruction of main vegetation and landscape change of the first half of the Holocene.

\section{MARINE GEOPHYSICAL EVIDENCE FOR ICE SHEET EXTENSION AND RECESSION ON THE MALIN AND NORTHWEST IRISH SHELVES: NEW EVIDENCE FOR THE WESTERN LIMITS OF THE BRITISH IRISH ICE SHEET}

Paul Dunlop. University of Ulster, United Kingdom

E-mail address: p.dunlop@ulster.ac.uk

Multibeam swath bathymetry data collected by the Irish National Seabed Survey provides evidence for extensive glaciation of the Malin Shelf, north of Ireland and on the shelf northwest of County Donegal. Streamlined subglacial bedforms on the mid to outer shelf record former offshoredirected ice flow and indicate the ice sheet was grounded in a zone of confluence between ice flowing onto the shelf from northwest Ireland and southwest Scotland. The major glacial features, however, consist of well developed arcuate moraines which mark the position of former ice sheet margins on various parts of the shelf. Distal to these moraines, on the outermost shelf, prominent zones of iceberg ploughmarks give way to the Barra/Donegal fan and a well developed system of gullies and canyons which incise the continental slope. The moraines record the episodic retreat of lobate grounded ice sheets across this sector of the continental shelf during deglaciation. Initial retreat from the outer shelf was associated with an episode of ice sheet breakup and calving as recorded by extensive zones of iceberg ploughmarks distal to the outermost moraines. This initial phase of retreat may have been driven by rising sea level. The data indicate a major reorganisation of the British Irish Ice Sheet on the shelf during deglaciation; an initial elongate ice sheet configuration extending along the shelf edge changed to a pronounced lobate form during retreat. Consideration of dated, marine stratigraphic records from the wider northwest margin suggests that ice sheet advance to the shelf edge likely occurred at about 29-27 cal ka BP, but that retreat from this shelf edge position did not take place until after $24 \mathrm{cal}$ ka BP. Large-scale contrasts in continental margin morphology west of Ireland, from trough mouth fans in the north to gully/canyon systems further to south, reflects a combination of factors including spatial variations in sediment flux related to palaeo-glaciology.

\section{GLACIAL GEOMORPHOLOGICAL MAP OF THE WESTERN MARGIN OF THE BRITISH IRISH ICE SHEET ON THE IRISH CONTINENTAL SHELF}

\section{Paul Dunlop. University of Ulster, United Kingdom}

E-mail address: p.dunlop@ulster.ac.uk

This poster presents the results of the first systematic mapping programme of the submerged glacial geomorphological record of the former British Irish Ice Sheet on the Irish Atlantic continental shelf. The mapping is based on interpretations of high resolution $(20 \mathrm{~m})$ multibeam swath bathymetry and backscatter data from the Irish National Seabed Survey (INSS), supplemented by medium resolution Olex data of the shelf west of Mayo, Clare and Galway which was not surveyed as part of the INSS. Both data sets provide evidence of glacial and glacially related landforms which reveals the pattern of shelf extensive glaciation and subsequent ice retreat along this part of the Atlantic margin. Streamlined subglacial bedforms on the mid to outer shelf and the Barra/Donegal Fan-Malin Deep glacial trough system in the northwest sector record former offshore-directed ice 
flow and former ice stream activity in the Malin Shelf region. However, the most striking geomorphological features along the entire margin are sequences of well developed kilometre scale arcuate moraine ridges that arch across the shelf to the northwest and west of Ireland. Distal to all of these moraines on the outermost shelf prominent zones of iceberg scours are evident and give way into a well developed system of gullies and canyons which incise the continental slope. The large-scale, arcuate moraines record the episodic retreat, probably punctuated by minor readvances or oscillations, of grounded ice sheet lobes along the entire western margin. The data indicates that a major reorganisation of the British Irish Ice Sheet occurred in this region during deglaciation from an initial elongate ice sheet configuration extending to the shelf edge to pronounced lobate forms during ice retreat.

\section{GLACIAL MOUNTAIN VEGETATION IN SOUTHERN AFRICA}

Lydie Dupont. University of Bremen / MARUM, Germany

E-mail address: dupont@uni-bremen.de

Terrestrial pollen records from southern Africa suggest a strong extension of the mountainous ericaceous vegetation during the Last Glacial. Here, we present a pollen record of the marine core MD96-2048 retrieved by the Marion Dufresne from the Indian Ocean $\sim 120 \mathrm{~km}$ south of the Limpopo River mouth ( $26^{\circ} 10^{\prime} \mathrm{S} 34^{\circ} 01^{\prime} \mathrm{E}$ in $660 \mathrm{~m}$ water depth). Our record corroborates the extension of open mountainous scrubland (including elements with affinity to the Cape Flora) for the Last Glacial as well as for other glacial periods of the past $300 \mathrm{ka}$.

The sedimentation at the site of MD96-2048 is slow and continuous. The upper 6 meters (down till $350 \mathrm{ka}$ ) have been analysed for pollen and spores at millennial resolution. The terrestrial pollen assemblages indicate that during interglacials the vegetation of eastern South Africa and southern Mozambique largely consisted of evergreen and deciduous forests. During glacials open mountainous shrubland dominated. Montane forest with Podocarpus was favoured during intermediate periods. The pattern strongly suggests a shifting of altitudinal vegetation belts in the mountains primarily depending on temperature, although the effects of low atmospheric carbon dioxide concentrations cannot be excluded. We compare our results from eastern South Africa with a marine pollen record from the eastern South Atlantic off the coast of Angola (ODP Site 1078). The vegetation and climate of southern Africa seems to follow a mid to high latitude rhythm, in which the glacial-interglacial contrast is more important than the precessional forced monsoon system of tropical Africa.

OPTICALLY STIMULATED LUMINESCENCE DATING OF THE 'LOST SARASWATI RIVER - THE ROLE OF CHANGING FLUVIAL ACTIVITY IN THE 'COLLAPSE’ OF THE INDUS VALLEY CIVILISATION

Julie Durcan. Institute of Geography and Earth Sciences, Aberyst, United Kingdom

E-mail address: jjd08@aber.ac.uk

The 'lost' Saraswati River is hypothesised to have flowed through modernday Pakistan and India during the mid-Holocene and to have been a primary source of water to the Indus Valley or Harappan civilisation, which occupied the area at this time. It has been suggested that a decline, and ultimately cessation, of flow in this river system in response to the weakening of the Asian Monsoon was influential in the collapse of this civilisation about 4,000 years ago. There is a strongly contested and ongoing debate as to the importance of climatic variability to the demise of the Harappan culture. Some authors advocate that controls such as tectonic activity are more influential upon fluvial activity in the region, while others argue that environmentally deterministic views ignore the importance of cultural development and evolution, and that the Harappans were able to adapt to variability in their environment, and that their civilisation did not collapse. This paper presents optically stimulated luminescence (OSL) dates from palaeochannel sediments and associated dune deposits that together constrain Holocene fluvial activity in the region. OSL dates indicate deposition of sediments by fluvial processes during the early to mid-Holocene, at a time when the Harappans were flourishing in the region, with aeolian deposition (and drier conditions) during the past millennium. This work permits for the first time a comparison between the documented archaeological record of the Harappan civilisation and an absolute chronology of regional fluvial activity. It also provides a direct test of whether the collapse/transformation of the Harappan civilisation can be correlated with regional climatic variability and/or local geomorphological change.

\section{SUBGLACIAL TUNNEL VALLEYS IN THE ALPINE FORELAND - AN EXAMPLE FROM BERN, SWITZERLAND}

Mirjam Dürst Stucki. Institute of Geological Sciences, Switzerland E-mail address: duerst@geo.unibe.ch

The morphology of the Alpine and adjacent landscapes is directly related to glacial erosion and associated sediment transport. Here we report the effects of glacio-hydrologic erosion on bedrock topography in the Swiss Plateau. Specifically, we identify the presence of subsurface valleys beneath the city of Bern and discuss their genesis. Stratigraphic investigations of more than 4000 borehole data within a $430 \mathrm{~km} 2$-large area reveal the presence of a network of $>200 \mathrm{~m}$-deep and $1000 \mathrm{~m}$-wide valleys. They are flat floored with steep sided walls and are filled by Quaternary glacial deposits. The central valley beneath Bern is straight and oriented towards the NNW, with valley flanks more than $20^{\circ}$ steep. The valley bottom has an irregular undulating profile along the thalweg, with differences between sills and hollows higher than $50-100 \mathrm{~m}$ over a reach of 4 kilometres length. Approximately $500 \mathrm{~m}$ high bedrock highlands flank the valley network. The highlands are dissected by up to $80 \mathrm{~m}$-deep and $500 \mathrm{~m}$-broad hanging valleys that currently drain away from the axis of the main valley. We interpret the valleys beneath the city of Bern to be a tunnel valley network which originated from subglacial erosion by melt water. The highland valleys served as proglacial meltwater paths and are hanging with respect to the trunk system, indicating that these incipient highland systems as well as the main gorge beneath Bern formed by glacial melt water under pressure.

\section{SIMULATING HOLOCENE SHIFTS IN EUROPEAN TREE SPECIES} DISTRIBUTION WITH DYNAMIC VEGETATION MODELS

Marie Dury. University of Liège, Belgium

E-mail address: marie.dury@ulg.ac.be

Pollen and macro-fossil data collected from various localities in Europe provide the opportunity to reconstruct the speed and the routes of the post-glacial spread of European tree species. Moving from a limited number of refugia at the end of the glacial period, tree species have progressively re-colonized the continent through the Holocene at seemingly species-specific migration rates. However, the relative roles of climatic fluctuations, dispersal capacities of individual species, and interspecific competition in controlling these rates remains controversial. Here, we investigate these different aspects with two dynamic vegetation models (DVM), LPJ-GUESS and CARAIB. Transient runs of both models were performed over the Holocene, using HadCM3 GCM-reconstructed climate. Large-scale species migration at $0.5^{\circ} \times 0.5^{\circ}$ is represented in these models using migration rates derived from a small-scale cellular automaton, CATS. Individual tree species migration rates were pre-calculated with CATS every 1000 years over each grid cell used by the DVMs in the climatic conditions reconstructed by the GCM. In the DVMs, these migration speeds were influenced by the response to competition from other species. The DVMs were used to study the migration of one species, from its $10 \mathrm{kyr}$ BP refugia, within a landscape defined by a set of other species for which no dispersal limitations are assumed. Here, we illustrate the results obtained for three wind-dispersed tree species: Abies alba, Picea abies, Fagus sylvatica and compare them to their past distributions reconstructed from pollen and macro-fossil data.

\section{THE IMPACT OF LATE-HOLOCENE ENVIRONMENTAL CHANGE ON THE MEDITERRANEAN MOUNTAINOUS BÜGDÜZ RIVER SYSTEM, SOUTHWEST TURKEY}

Bert Dusar. K.U.Leuven, Belgium

E-mail address: Bert.Dusar@ees.kuleuven.be 